Brit. J. industr. Med., 1956, 13, 119.

\title{
A SOCIAL AND OCCUPATIONAL STUDY OF INJURED HANDS
}

\author{
BY \\ RUTH WILKES \\ From the Nuffield Department of Industrial Health, University of Durham \\ (King's College, Newcastle upon Tyne)
}

(RECEIVED FOR PUbliCATION OCTOBER 7, 1955)

Most of us depend on our hands for our livelihood. Even today when the skilled hand of the craftsman has largely been replaced by the simpler movements of the machine minder, very little can be done in industry without the skilled use of the worker's hands, and the effects of an injury to the hand are probably no less than the effects of damage to the eye or to the head.

The objects of this study were : (1) to find out the causes of hand injuries amongst a group of men working in the north east of England; (2) to record the opinions of these men about why their injury happened; (3) to discuss prevention; (4) to enquire into the cost of these hand injuries, measured in terms of money and time lost by the men ; and (5) to make an intensive study of a group of more severely injured men to find out the effect of the injury on their social and working lives, and to make some kind of assessment of residual disability.

It must be emphasized that the approach was not a medical one and that only the social, economic, and occupational aspects were considered. Problems of surgical technique and treatment are outside the scope of this study, although it is true that the social and medical aspects cannot be completely separated and that some overlapping of interests is inevitable.

The research included infections as well as injuries of the hand, but since the two conditions present rather different problems, they have been dealt with separately. The results of the work on infected hands have been published elsewhere (Wilkes, 1954), and they will not be considered in this paper. It may be of some interest, however, to mention that the men with infected hands were usually away from work for two to four weeks, and that 45 men $(30 \%)$ had no known history of injury. Injuries which gave rise to infection were trivial ones, and were usually caused by knocking the hand against something rough or sharp. There was no evidence of any unreasonable neglect of the injury.

The method of study was described in detail in the paper dealing with hand infections, and it need only be said here that, for the most part, the data are based on information given by the men during one or more interviews. The men were all attending the hand clinic of the department of surgery in the Royal Victoria Infirmary, Newcastle upon Tyne.

The Men Interviewed

Two hundred and ninety-seven men were interviewed during the period March to December, 1952. Forty per cent. (119) were miners, and the other large occupational groups were engineers (70), woodworkers (30), and workers in unskilled occupations (23). The remaining occupational groups were made up of workers in the building trade (8), transport workers (6), slingers and crane drivers, and a small number of professional workers, agricultural workers, unemployed men, and men in other occupations. Nearly all the men came from industries in and around Newcastle and from pits in Northumberland and Durham, and they attended the clinic immediately after the injury. The ages of the men ranged from 15 to 65 years, but $86.5 \%$ (257) were under 55 . There were 41 men $(13.8 \%)$ under the age of 20 . There were no women or children.

\section{The Diagnoses}

The diagnosis of a hand injury is complicated because there is often more than one feature. Table 1 shows that in the present series approximately one half of the men had more than one kind of injury. Nearly half the injuries (141) involved a laceration, 77 injuries involved a joint or bone, and 62 involved a loss of skin sufficient to need a graft. Traumatic amputations (50), tendon injuries (49), and crush injuries (45) were also common. The 
TABLE 1

CLASSIFICATION OF INJURIES

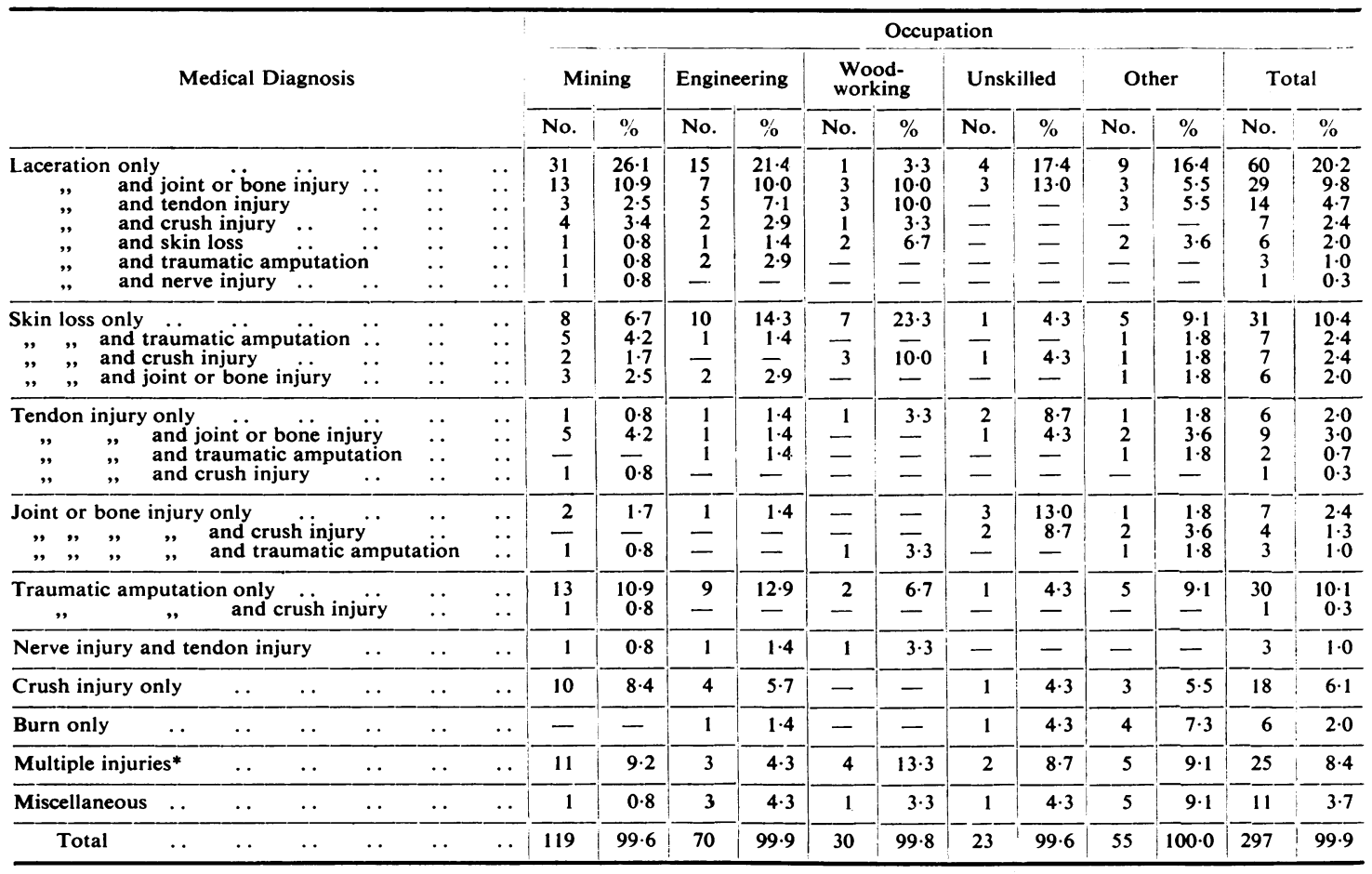

* "Multiple injuries" means more than two kinds of injury.

injuries were severe enough to keep the man off work, and all the men were admitted to the hostel attached to the hand clinic where the usual length of stay was one week. Some of the more severe injuries were excluded because when extensive grafting is required immediately, the injured man goes straight to the plastic unit and is not seen in the hand clinic at all.

\section{Anatomical Site}

Table 2 shows the parts of the hand involved in the injuries. It is interesting to note that there were almost as many injuries to the left hand as to the right, and the woodworkers actually had more left-hand injuries. Finger injuries were by far the most common. Two hundred and twenty-three of the injuries $(75.1 \%)$ occurred to one or more fingers only, and 37 of the injuries $(12.5 \%)$ were to the thumb only. The remainder were to the palm or the dorsum or the wrist only, or to the thumb and one finger or to some other combination of the parts of the hand.

\section{The Cause of the Injury}

Statements made by the injured person do not give the whole story of how and why an accident happened, but it was thought that something could be

TABLE 2

SITE OF THE INJURY

\begin{tabular}{|c|c|c|c|c|c|c|c|}
\hline Occupation & Thumb & $\begin{array}{c}\text { Thumb } \\
\text { and } \\
\text { Finger(s) }\end{array}$ & $\begin{array}{c}\text { Finger(s) } \\
\text { Only }\end{array}$ & Palm & $\begin{array}{l}\text { Dor- } \\
\text { sum }\end{array}$ & Other & Total \\
\hline $\begin{array}{l}\text { Right hand } \\
\text { Mining } \quad . \\
\text { Engineering } . . \\
\text { Woodworking } \\
\text { Unskilled . } \\
\text { Transport a. } \\
\text { Building and } \\
\text { contracting } \\
\text { Others }\end{array}$ & $\begin{array}{r}6 \\
2 \\
4 \\
3 \\
- \\
-1\end{array}$ & $\begin{array}{l}\frac{\overline{1}}{\overline{1}} \\
1^{*}\end{array}$ & $\begin{array}{r}54 \\
30 \\
9 \\
6 \\
1 \\
4 \\
16\end{array}$ & $\begin{array}{l}\frac{2}{1} \\
1 \\
1\end{array}$ & $\begin{array}{l}\frac{1}{2} \\
= \\
-1\end{array}$ & $\begin{array}{l}4 \\
2 \\
二 \\
- \\
-\end{array}$ & $\begin{array}{r}67 \\
36 \\
14 \\
10 \\
2 \\
6 \\
19\end{array}$ \\
\hline Total & 16 & 3 & 120 & 5 & 4 & 6 & 154 \\
\hline $\begin{array}{l}\text { Left hand } \\
\text { Mining } \\
\text { Engineering ... } \\
\text { Woodw orking } \\
\text { Unskilled .. } \\
\text { Transport .. } \\
\text { Building and } \\
\text { contracting } \\
\text { Others .. }\end{array}$ & $\begin{array}{l}6 \\
5 \\
1 \\
2 \\
- \\
1 \\
6\end{array}$ & $\begin{array}{r}1 \\
\frac{1}{2} \\
- \\
-1\end{array}$ & $\begin{array}{r}37 \\
26 \\
13 \\
9 \\
4 \\
1 \\
13\end{array}$ & $\begin{array}{l}\frac{3}{2+} \\
- \\
-\end{array}$ & $\begin{array}{l}4 \\
1 \\
- \\
- \\
-1\end{array}$ & $\begin{array}{l}1 \\
1 \\
二 \\
- \\
1\end{array}$ & $\begin{array}{r}52 \\
34 \\
16 \\
13 \\
4 \\
2 \\
22\end{array}$ \\
\hline Total .. & 21 & 5 & 103 & 5 & 6 & 3 & $1 \overline{143}$ \\
\hline Grand total . . & 37 & 8 & 223 & 10 & 10 & 9 & 297 \\
\hline Percentage & 12.5 & $2 \cdot 7$ & $75 \cdot 1$ & 3.4 & $3 \cdot 4$ & 3.0 & $\overline{100 \cdot 1}$ \\
\hline
\end{tabular}

*Also injured left hand slightly. † Also injured right hand slightly. 
TABLE 3

THE CAUSE OF THE INJURY (AT WORK ONLY)

\begin{tabular}{|c|c|c|c|c|c|c|c|c|c|c|c|c|c|c|c|c|}
\hline \multirow[b]{2}{*}{$\begin{array}{l}\text { Cause of the } \\
\text { Injury }\end{array}$} & \multicolumn{16}{|c|}{ Occupation } \\
\hline & \multicolumn{2}{|c|}{ Mining } & \multicolumn{2}{|c|}{ Engineering } & \multicolumn{2}{|c|}{$\begin{array}{l}\text { Wood- } \\
\text { working }\end{array}$} & \multicolumn{2}{|c|}{ Unskilled } & \multicolumn{2}{|c|}{ Transport } & \multicolumn{2}{|c|}{$\begin{array}{l}\text { Building and } \\
\text { Contracting }\end{array}$} & \multicolumn{2}{|c|}{ Other } & \multicolumn{2}{|c|}{ Total } \\
\hline $\begin{array}{l}\text { Machinery } \\
\text { Handling goods } \\
\text { Struck by falling body } \\
\text { Moving objects } \\
\text { Use of hand tools . } \\
\text { Struck by rising body } \\
\text { Persons falling } \\
\text { Striking against objects } \\
\text { Other . . . . . }\end{array}$ & $\begin{array}{r}13 \\
12 \\
39 \\
32 \\
2 \\
11 \\
6 \\
2\end{array}$ & $\begin{array}{l}11 \cdot 1 \\
10 \cdot 3 \\
33 \cdot 3 \\
27 \cdot 3 \\
1 \cdot 7 \\
9 \cdot 4 \\
5 \cdot 1 \\
\overline{1 \cdot 7}\end{array}$ & $\begin{array}{r}35 \\
13 \\
5 \\
5 \\
1 \\
3 \\
3\end{array}$ & $\begin{array}{r}53 \cdot 8 \\
20 \cdot 0 \\
7 \cdot 7 \\
\overline{7} \\
1 \cdot 7 \\
4 \cdot 6 \\
\overline{4 \cdot 6}\end{array}$ & $\begin{array}{r}25 \\
1 \\
\frac{2}{2} \\
1 \\
1\end{array}$ & $\begin{array}{l}83 \cdot 3 \\
3 \cdot 3 \\
\overline{-} \\
6 \cdot 7 \\
\overline{3 \cdot 3} \\
3 \cdot 3 \\
-\end{array}$ & $\begin{array}{r}6 \\
10 \\
1 \\
2 \\
1 \\
- \\
2\end{array}$ & $\begin{array}{c}27 \cdot 3 \\
45 \cdot 5 \\
4 \cdot 5 \\
9 \cdot 1 \\
\overline{4 \cdot 5} \\
= \\
\overline{9} \cdot 1\end{array}$ & $\begin{array}{l}\frac{1}{2} \\
\frac{1}{1} \\
\frac{1}{1} \\
-\end{array}$ & $\begin{array}{l}16 \cdot 7 \\
33 \cdot 3 \\
16 \cdot 7 \\
16 \cdot 7 \\
\overline{16 \cdot 7} \\
-\end{array}$ & $\begin{array}{r}1 \\
1 \\
1 \\
1 \\
\frac{2}{1} \\
-1\end{array}$ & $\begin{array}{l}12.5 \\
12.5 \\
12.5 \\
12.5 \\
25.0 \\
\overline{12.5} \\
\overline{12.5}\end{array}$ & $\begin{array}{r}13 \\
11 \\
1 \\
3 \\
\frac{1}{2}\end{array}$ & 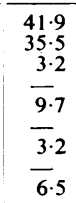 & $\begin{array}{r}94 \\
50 \\
47 \\
36 \\
15 \\
13 \\
12 \\
2 \\
10\end{array}$ & $\begin{array}{r}33.7 \\
17.9 \\
16.8 \\
12.9 \\
5.4 \\
4.7 \\
4.3 \\
0.7 \\
3.6\end{array}$ \\
\hline Total & 117 & 99.9 & 65 & 99.9 & 30 & 99.9 & 22 & $100 \cdot 0$ & 6 & $100 \cdot 1$ & 8 & $100 \cdot 0$ & 31 & $100 \cdot 0$ & 279 & $100 \cdot 0$ \\
\hline
\end{tabular}

learned by asking the patient to give details of his accident and to say what he thought had caused it. It is seldom easy to know exactly why an accident happened, especially for those who are involved in it, and the value of this part of the study largely depends on the honesty and intelligence of the men who were questioned.

Two hundred and seventy-nine of the injuries occurred at work and 18 injuries were the result of acridents at home, on the road, or elsewhere.

Table 3 sets out the causes of the injuries occurring at work. A little over a third (33.7\%) of the injuries were caused by machinery. This emphasizes the severity of the injuries and is in accordance with the findings of Rank and Wakefield (1953) who noted that among 1,000 cases of hand injuries which involved hospital admission a high proportion were due to machinery. It is perhaps surprising that in the present series a higher proportion was not caused by machinery, but it should be remembered that $40 \%$ of the men were miners, and in spite of the increasing mechanization of the pits comparatively few mining accidents are caused by machinery. If the miners are omitted the proportion of accidents caused by machinery rises to a half.

Two-thirds of the machinery accidents happened to workers in the engineering and woodworking trades. This is not surprising since workers in these occupations are particularly exposed to this risk. Eighteen of the men $(19 \%)$ involved in machinery accidents mentioned speed of working as a chief cause of the accident.

Case 1.-A 16-year-old wood machinist amputated the right index and middle fingers when he ricked up a block of wood from the table of a rotating circular saw. It is the practice in his firm to remove blocks of wood by hand after they are cut, and since the blocks are touching the saw it is clearly a dangerous practice even when the blocks are large. On this occasion the block was only two inches long and the boy's hand was easily caught on the saw. The boy knew that the correct method of removing blocks of any size is by using a push stick, but he said that nobody bothers to do this as it is quicker and less trouble to use the hand. He only did what he had seen the men doing.

Twelve men blamed their machines for their accident, and amongst these were three who said their machines had no guard, and one man who worked a planing machine and described the guard as "laughable".

Case 2.-A bakery worker was cleaning dough out of a divider when the clutch slipped, and the blade moved forward cutting off all the fingers of his right hand. He said that the divider was an old machine and it had not been properly maintained. The only safe way to clean the divider was by turning off the electricity, but this was never done because there was only one switch for the whole plant, and the divider could not be stopped without stopping other machines on the same circuit. After the accident the divider was built up on three sides so that no one could get a hand in, and an automatic safety device was put on the cutter. The method of cleaning the dough cutter was also altered, and the divider cannot now be cleaned unless the electricity is cut off at the source by the foreman, and the machine dismantled. This method takes half an hour whereas the previous method of using the clutch as a brake, standing on the conveyor belt supports, and putting a hand in at the top of the hopper took two minutes.

In two instances the design rather than the maintenance of the machine seems to have been at fault.

Case 3.-A lathe was being worked by a boy of 15 years and because of his smallness he had to lean over the machine to tighten the key in the chuck. As he did so his thigh touched the starter and set the machine off. The middle finger of his right hand was lacerated when the key came round and jammed the hand against the bed of the machine. The boy thought it would have been better if the starter had either been shrouded or had not been the kind that starts at a touch. 
Woodworking machinery accidents were sometimes attributed to faults in the wood, as for example a knot causing the wood to jump. Some men were critical of the foreign timber now being used in some factories. This wood was said to be badly cut and seasoned, and it was kiln dried, which one man said " takes the nature out of the wood".

Twelve of the machinery accidents were attributed, at least in part, to inexperience or lack of proper instruction. These reasons naturally apply particularly to young people, but adults too became involved in accidents when they were using machines they did not normally use or doing work to which they were not accustomed.

Case 4.-One of the mining accidents occurred when a datal (day rate) worker, who was normally employed as a bricklayer's labourer in the pit, was helping with some of the general labouring work because there was no bricklaying work to be done that day. The accident happened when he was putting some cable on to a conveyor belt and someone set the belt away unexpectedly, jamming his fingers against the box end. If work on the conveyor belt had been his regular job he would have been more efficient with his signals. $\mathrm{He}$ added that they were not supposed to put cable on the conveyor belts but he had been told to do it.

Case 5.-Lack of supervision was blamed for an accident occurring to a 15-year-old apprentice fitter. He was cleaning a screwing machine when a bolt came round on the chuck and jammed his left thumb. He had worked the machine for one month and had originally been shown how to work it by another apprentice fitter, aged 16 years. After the first two days he was left in sole charge, and he thought his accident would not have happened if there had been someone to remind him of the dangers of his machine. His accident happened at the start of the day, and he was glancing up at the clock when he felt his hand being drawn into the machine.

A misunderstanding was a cause of some machinery accidents, as in the example quoted above when the conveyor belt was set away unexpectedly. Some accidents, especially on grindstones, were undoubtedly caused when the man relaxed his grip, perhaps because he was tired or his hands were cold. The danger of wearing loose clothing near moving machinery was illustrated by two accidents where clothing became involved in conveyor belt rollers and one accident where a man's safety glove was caught in a flanging machine.

Fifty accidents $(17.9 \%)$ occurred to men when they were using their hands to move objects from one place to another or on and off machines. In this paper, accidents involving lifting machinery, whether moved by power or not, are included in the " handling goods" category provided that the man was injured while his hands were in contact with the load. Fourteen accidents $(28.0 \%)$ in this group involved the use of cranes and occurred to slingers. These accidents often occurred when the load toppled over in the sling as the slinger was guiding, loading, or unloading the sling. Misunderstanding between slinger and crane driver caused six accidents, and the misunderstanding arose either because the wrong signal was given or because the crane driver was not looking, or was unable to see because of the position of his box. Other " handling goods" accidents happened when the object being handled was slippery or difficult to grip, and a number of objects toppled over at a touch for no reason at all that the man could think of. In general, crane accidents excepted, accidents caused by handling were considered to be unavoidable. To the injured man his accident was just " one of those unforeseen things ".

Of 117 accidents to miners, $39(33.3 \%)$ were caused by something falling. Often ( 26 accidents) the object falling was a piece of stone and this usually came from the roof, although in three instances the man was injured by a stone thrown by his mate. Other injuries to miners were caused by girders or props falling over and these accidents usually happened when men lost their balance while putting up props, or were in too much of a hurry to do the job correctly. Falls of stone are difficult to prevent but two miners remarked that these accidents are often caused by good stone rather than bad, the implication being that more risks are taken with good stone, whereas men usually watch bad stone and take care to see that the roof is propped as it should be.

Over a quarter of the mining accidents were caused by tubs or trams running over or crushing the hand. These accidents happened to men when they were pushing tubs or trams (15 accidents), coupling or uncoupling tubs (seven accidents), clipping or unclipping sets (seven accidents), or braking tubs with drags (three accidents). Often (14 accidents) the man's hand was caught between two tubs. Five of the accidents involved ponies, and three of these were said to have happened because the man involved was not used to ponies and did not understand the pony he was dealing with. Other men said that they had been rather slow in getting out of the way of the tubs or that they had put their hands in the wrong place, although there seems to be no safe place for hands to be put when handling tubs since hands were hit when they were at the back, on the top, and at the side of tubs. The most frequent complaint was that there was not enough room between the tubs when they were standing buffer to buffer. 
Other injuries were caused by hand tools or by falls, and in the pits 11 injuries were caused by girders or tubs rising and crushing the man's hand against the roof. These " rising bodies" accidents happened when a tub hit some obstruction or a joint in the rail and the back of the tub jumped up, or when one end of a girder or prop went down and the other end went up and hit the roof. Eight of the 15 injuries caused by hand tools were attributed to hammers, and five were caused by knives slipping. The falls were all on the flat and were caused by tripping or slipping either because the floor had not been kept clear or because there was oil or ice on the ground.

Case 6.-One of the worst injuries occurred to a miner who had gone down the pit carrying a glass medicine bottle full of oil for his pneumatic pick. He tripped over a stone and the bottle smashed in his hand as he hit the ground. His hand was badly cut across the palm and the residual disability was severe.

It was not possible to classify all the contributory factors mentioned, and a number of patients had no idea at all why their accident had happened. They could only say they had been careless and had put their hands in the wrong place. Often accidents were described as "a chance in a thousand" and not likely to happen again.

There were 18 injuries resulting from nonindustrial accidents, eight of which were accidents in the home, two on the road, two on the playing fields, and six others.

\section{Prevention}

The above analysis of the causes of hand injuries indicates ways in which these accidents might be prevented. Some of the machinery accidents would not have happened if the machines had been well designed and well guarded, and some woodworking machinery accidents might have been prevented by the use of good, well-seasoned wood. In general many accidents of all kinds would be prevented if men and managements cooperated to ensure that the speed of working allowed men enough time to make the best use of all safeguards. Piece rates and bonus systems of payment were blamed for accidents more often than anything else because the men said that they were in too much of a hurry to be careful ; but it should be said that the blame for this does not belong entirely to managements since the men themselves often prefer to take risks rather than have their earnings reduced. Lack of adequate supervision seemed to be the cause of some accidents, and there were several instances of young people who had received no instruction or supervision after their first day or first time on the machine.
In the pits hand accidents usually occurred on haulage work or when stone fell from the roof. Falls of stone seem to be unpreventable unless they occur when the roof has not been propped correctly, and even then some stones become dislodged. Several miners suggested that many haulage accidents would be prevented if another inch or two were added to the buffers on tubs and trams, although this would add considerably to the total length of sets of tubs and might be impracticable on that account. The present length of tub buffers is about two and a half to three inches, giving a clearance space of five to six inches when two tubs are buffered together. Some of the miners said this was not a large enough clearance for a man's hand. Whitfield (1946) has pointed out that there would be more space between tubs when they were being coupled and uncoupled if this was done on a curve and not on a straight road, because on a curve only the inside buffers come into contact, leaving a safe working space on the outside for uncoupling. But it is not always possible to curve the track, and it might be as effective to couple tubs in the normal way, i.e., with one hand on top of the tub and the other hand coupling the tub from underneath the buffers, but with longer buffers so that there is more room to manoeuvre between tubs.

Many accidents were due to personal factors, e.g., misunderstanding, misjudgment, and lack of attention or thought. It is easy to be wise about these accidents after they have happened but it is difficult to know how to prevent them.

\section{The Cost of the Injury}

An attempt has been made to assess the personal hardship and loss to individual men in the follow-up study, and information concerning the financial cost and the time lost from work was obtained from nearly all the men.

Financial Cost.-Table 4 gives an idea of the amount of money lost each week while the man was off work, but it does not give the whole picture. Many of the men eventually made up what they had lost if they received income tax relief, disablement benefit, or awards for damages. On the whole those with any residual disability tended to gain financially from their injury since they were not off work long enough for the accumulated weekly loss to exceed the amount paid to them in disablement benefit. But in these instances money gain was, of course, paid for by some permanent impairment of hand function or loss of a part of a hand.

The weekly loss for men while they were off work varied around a mid-point of $£ 310$ s., but miners and engineers often suffered income losses of over 
TABLE 4

DIFFERENCE BETWEEN USUAL EARNINGS AND INCOME DURING ILLNESS

\begin{tabular}{|c|c|c|c|c|c|c|c|c|c|c|c|c|c|c|c|c|c|}
\hline \multirow{3}{*}{ Weekly Loss } & & \multicolumn{16}{|c|}{ Occupation } \\
\hline & & \multicolumn{2}{|c|}{ Mining } & \multicolumn{2}{|c|}{ Engineering } & \multicolumn{2}{|c|}{$\begin{array}{l}\text { Wood- } \\
\text { working }\end{array}$} & \multicolumn{2}{|c|}{ Unskilled } & \multicolumn{2}{|c|}{ Transport } & \multicolumn{2}{|c|}{$\begin{array}{l}\text { Building and } \\
\text { Contracting }\end{array}$} & \multicolumn{2}{|c|}{ Other } & \multicolumn{2}{|c|}{ Total } \\
\hline & & No. & $\%$ & No. & $\%$ & No. & $\%$ & No. & $\%$ & No. & $\%$ & No. & $\%$ & No. & $\%$ & No. & $\%$ \\
\hline $\begin{array}{l}\text { No change } \\
\text { Less than } £ 1 \text {. } \\
£ 1-£ 1 \text { 19s. Od. } \\
£ 2-£ 2 \text { 19s. Od. } \\
£ 3-£ 3 \text { 19s. Od. } \\
£ 4-£ 4 \text { 19s. Od. } \\
£ 5-£ 5 \text { 19s. 0d. } \\
£ 6-£ 6 \text { 19s. Od. } \\
£ 7-£ 7 \text { 19s. 0d. } \\
£ 8 \text { and over .. } \\
\text { Other .. } \quad . .\end{array}$ & $\begin{array}{l}\cdots \\
\cdots \\
\cdots \\
\cdots \\
\cdots \\
\cdots \\
\cdots \\
\cdots\end{array}$ & $\begin{array}{r}2 \\
8 \\
13 \\
14 \\
15 \\
9 \\
17 \\
14 \\
8 \\
19 \\
-\end{array}$ & $\begin{array}{r}1 \cdot 7 \\
6.7 \\
10.9 \\
11 \cdot 8 \\
12.6 \\
7.6 \\
14 \cdot 3 \\
11 \cdot 8 \\
6.7 \\
16.0 \\
-\end{array}$ & $\begin{array}{r}3 \\
12 \\
4 \\
9 \\
7 \\
12 \\
9 \\
8 \\
6 \\
\end{array}$ & $\begin{array}{r}4 \cdot 3 \\
17 \cdot 1 \\
5.7 \\
12.9 \\
10 \cdot 0 \\
17 \cdot 1 \\
12.9 \\
11.4 \\
\frac{8.6}{-}\end{array}$ & $\begin{array}{l}2 \\
1 \\
3 \\
5 \\
8 \\
5 \\
1 \\
2 \\
1 \\
2\end{array}$ & \begin{tabular}{r|}
$6 \cdot 7$ \\
$3 \cdot 3$ \\
$10 \cdot 0$ \\
$16 \cdot 7$ \\
$26 \cdot 7$ \\
$16 \cdot 7$ \\
$3 \cdot 3$ \\
$6 \cdot 7$ \\
$3 \cdot 3$ \\
$6 \cdot 7$
\end{tabular} & $\begin{array}{l}1 \\
1 \\
2 \\
7 \\
2 \\
7 \\
2 \\
1 \\
- \\
-\end{array}$ & \begin{tabular}{r|}
$4 \cdot 3$ \\
$4 \cdot 3$ \\
$8 \cdot 7$ \\
$30 \cdot 4$ \\
$8 \cdot 7$ \\
$30 \cdot 4$ \\
$8 \cdot 7$ \\
$4 \cdot 3$ \\
- \\
-
\end{tabular} & $\begin{array}{l}\frac{1}{1} \\
\frac{1}{1} \\
\frac{1}{1} \\
-\end{array}$ & $\begin{array}{l}16 \cdot 7 \\
\overline{16 \cdot 7} \\
16 \cdot 7 \\
\overline{16 \cdot 7} \\
\overline{16 \cdot 7} \\
16 \cdot 7 \\
-\end{array}$ & $\begin{array}{l}- \\
1 \\
4 \\
2 \\
1 \\
- \\
- \\
-\end{array}$ & $\begin{array}{l}- \\
\overline{12.5} \\
50.0 \\
25.0 \\
12.5 \\
- \\
- \\
-\end{array}$ & $\begin{array}{r}10 \\
3 \\
3 \\
5 \\
12 \\
1 \\
3 \\
1 \\
2 \\
1\end{array}$ & $\begin{array}{r}24 \cdot 4 \\
7 \cdot 3 \\
7 \cdot 3 \\
12 \cdot 2 \\
29 \cdot 3 \\
2 \cdot 4 \\
7 \cdot 3 \\
2 \cdot 4 \\
4 \cdot 9 \\
2 \cdot 4\end{array}$ & $\begin{array}{r}19 \\
25 \\
27 \\
45 \\
34 \\
47 \\
30 \\
29 \\
10 \\
28 \\
3\end{array}$ & $\begin{array}{r}6.4 \\
8.4 \\
9.1 \\
15.2 \\
11.4 \\
15.8 \\
10 \cdot 1 \\
9.8 \\
3.4 \\
9.4 \\
1.0\end{array}$ \\
\hline Total & $\ldots$ & 119 & $100 \cdot 1$ & 70 & $100 \cdot 0$ & 30 & $100 \cdot 1$ & 23 & 99.8 & 6 & $\mid 100 \cdot 2$ & 8 & $100 \cdot 0$ & 41 & 99.9 & 297 & $100 \cdot 0$ \\
\hline
\end{tabular}

$£ 8$ a week, and the largest drop in income was to a miner who lost about $£ 14$ a week. Seventeen men, said there would be no change in their financial circumstances for the first few weeks they were off work, and there were two old-age pensioners whose income was unaffected. Two men actually gained a few shillings each week, and one man who was self-employed was unable to make any estimate of weekly gain or loss.

The employer, and ultimately the country, suffers too when a worker loses time through injury since the man has either to be replaced by another worker, in which case there is a man short in some other department, or he is not replaced and his mates either have to work harder, work overtime, or else production suffers. The self-employed are often hit the hardest since their work sometimes stops altogether and with it their income.

Time Lost from Work.-Information about the amount of time lost from work was supplied by all but $13(4.4 \%)$ of the men, and this information is set out in Table 5. This Table shows that over three-fifths $(65.3 \%)$ started work within eight weeks, and over four-fifths $(82.1 \%)$ were back at work by the end of 12 weeks. Of the remaining 53 men, two were old-age pensioners who were not working and 13 provided no information. This leaves 38 men $(12.7 \%)$ who were known to have been off work for more than 12 weeks, and 12 of these $(4.0 \%)$ were off work for six months or more. Four men were off work for more than a year, and the longest period of incapacity was two years and eight months. The median duration for all the men was seven weeks. It is difficult to find comparable figures, but Barclay (1955a) in a study of 52 patients with finger tip injuries found that the average amount of time lost by patients who had had the finger amputated was 11.5 weeks, and when a free graft had been applied the average was nine weeks.
The medians were 10 and eight weeks respectively (Barclay, 1955b). In the present series there were 90 men with finger tip injuries treated by amputation or free graft, and the median amount of time lost from work was six weeks for amputations and seven weeks for grafts. Barclay found that patients with finger tip amputations do not as a rule return to work for a comparatively long time and he suggested that it may take from two to three months for the stumps to harden enough for the injured person to undertake heavy work, and when machinery is involved it may take the same length of time for the man's confidence to be restored.

Some of the men in the present series were off work for a considerable time, but from the figures alone it is not possible to know whether or not there was any undue delay in returning to work.

Return to Work Related to Hand Clinic's Advice.It is the policy of the Hand Clinic to discharge patients only when the hand has healed, and it is at this point that they are usually advised to start work, although some are given this advice during treatment. Table 6 shows that 54 men were advised to start work during treatment and that three men had already started work when this advice was given. One hundred and fifty-three men were discharged healed and fit for work. Of these 207 men, $85(41 \%)$ started work during the week after discharge or the clinic's advice to them to start work. Three men started work a week or two before advice and the remaining $119 \quad(57.5 \%)$ delayed for periods varying from two weeks to two months or more. The longest delay was 42 weeks. In addition, 12 men discharged themselves from the clinic and started work within a week of their last attendance. Twenty men presumably decided to attend their own doctors, since they did not come back to the clinic, but nevertheless they were off 
TABLE 5

LENGTH OF TIME OFF WORK

\begin{tabular}{|c|c|c|c|c|c|c|c|c|c|c|c|c|c|c|c|c|}
\hline \multirow{3}{*}{$\begin{array}{l}\text { Weeks off } \\
\text { Work }\end{array}$} & \multicolumn{14}{|c|}{ Occupation } & & \\
\hline & \multicolumn{2}{|c|}{ Mining } & \multicolumn{2}{|c|}{ Engineering } & \multicolumn{2}{|c|}{$\begin{array}{l}\text { Wood- } \\
\text { working }\end{array}$} & \multicolumn{2}{|c|}{ Unskilled } & \multicolumn{2}{|c|}{ Transport } & \multicolumn{2}{|c|}{$\begin{array}{l}\text { Building and } \\
\text { Contracting }\end{array}$} & \multicolumn{2}{|c|}{ Other } & \multicolumn{2}{|c|}{ Total } \\
\hline & No. & $\%$ & No. & $\%$ & No. & $\%$ & No. & $\%$ & No. & $\%$ & No. & $\%$ & No. & $\%$ & No. & ${ }_{0}$ \\
\hline $\begin{array}{l}1 \\
2 \\
3 \\
4\end{array}$ & $\left.\mid \begin{array}{r}-1 \\
1 \\
5 \\
8\end{array}\right)$ & $11 \cdot 8$ & $\begin{array}{c}-3 \\
5 \\
9\end{array}$ & $24 \cdot 3$ & $\begin{array}{l}-2 ! \\
1 \\
4\end{array}$ & $23 \cdot 3$ & $\left.\begin{array}{l}1 \\
2\end{array}\right)$ & $30 \cdot 4$ & $\frac{1}{1} j$ & $50 \cdot 0$ & $\frac{2}{-1}$ & $37 \cdot 5$ & $\left.\begin{array}{l|}1 \\
6 \\
2 \\
2\end{array}\right)$ & $26 \cdot 8$ & $\begin{array}{r}5 \\
151 \\
15 \\
27\end{array}$ & $20 \cdot 9$ \\
\hline $\begin{array}{l}5 \\
6 \\
7 \\
8\end{array}$ & $\begin{array}{l}13 \\
16 ! \\
16 ! \\
10\end{array}$ & $46 \cdot 2$ & $\begin{array}{r}15 \\
4 \\
13 \\
6\end{array} \mid$ & $54 \cdot 3$ & $\left.\begin{array}{l}5 \\
3 \\
5 \\
2\end{array}\right)$ & $50 \cdot 0$ & \begin{tabular}{l|l}
1 \\
3 & 1 \\
5 & 1 \\
1
\end{tabular} & $43 \cdot 5$ & E & - & $\begin{array}{l}2 \\
2 \\
-1\end{array}$ & $50 \cdot 0$ & $\begin{array}{l}2 \\
1 \\
3 \\
4\end{array} !$ & $24 \cdot 4$ & $\left.\begin{array}{l}38 \\
29 \\
42 \\
23\end{array}\right)$ & $44 \cdot 4$ \\
\hline $9-12$ & 27 & $22 \cdot 7$ & 5 & $7 \cdot 1$ & 5 & $16 \cdot 7$ & 2 & $8 \cdot 7$ & 2 & $33 \cdot 3$ & - & 一 & 9 & $22 \cdot 0$ & 50 & $16 \cdot 8$ \\
\hline $13-16$ & 8 & $6 \cdot 7$ & 1 & 1.4 & 1 & $3 \cdot 3$ & 1 & $4 \cdot 3$ & 1 & $16 \cdot 7$ & - & - & -1 & - & 12 & $4 \cdot 0$ \\
\hline $17-20$ & 6 & $5 \cdot 0$ & - & - & - & - & 1 & $4 \cdot 3$ & - & - & - & - & 3 & $7 \cdot 3$ & 10 & 3.4 \\
\hline $21-24$ & 1 & 0.8 & 2 & $2 \cdot 9$ & - & - & - & - & - & - & 1 & $12 \cdot 5$ & - & - & 4 & $1 \cdot 3$ \\
\hline 25 and over & 6 & $5 \cdot 0$ & 3 & $4 \cdot 3$ & - & - & 1 & $4 \cdot 3$ & - & - & - & - & 2 & 4.9 & 12 & $4 \cdot 0$ \\
\hline Not known & 2 & $1 \cdot 7$ & 4 & $5 \cdot 7$ & 2 & $6 \cdot 7$ & 1 & $4 \cdot 3$ & - & - & - & - & 4 & $9 \cdot 8$ & 13 & $4 \cdot 4$ \\
\hline Not applicable & - & - & - & - & - & - & - & 一 & - & - & - & - & 2 & $\overline{4 \cdot 9}$ & 2 & 0.7 \\
\hline Total & 119 & 99.9 & 70 & $100 \cdot 0$ & 30 & $100 \cdot 0$ & 23 & $99 \cdot 8$ & 6 & $100 \cdot 0$ & 8 & $100 \cdot 0$ & 41 & $100 \cdot 1$ & 297 & 99.9 \\
\hline
\end{tabular}

work for two weeks or more after their last attendance. Forty-one men returned to work before they were discharged from the clinic or before their last attendance. On the face of it it seems that these men returned to work before the clinic had advised them to do so, but it is possible that in some cases the men were advised to start work but no mention was made of it in the medical notes.

No special study was made to find out why there is sometimes a discrepancy between what the surgeon advised the man to do and what the man actually did, but the subject was raised with some of those who were interviewed on follow-up, and it is clear that there was more than one reason why men delayed returning to work. The following explana-

TABLE 6

RETURN TO WORK RELATED TO ADVICE OF CLINIC (TOTAL 280 PAT́TIENTS)

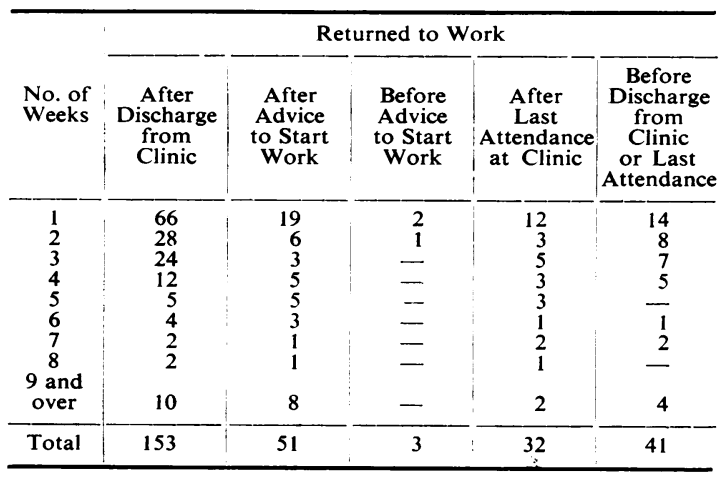

tions were offered : (1) his own doctor advised him not to start work immediately; (2) he made his own decision not to start work immediately. $\mathrm{He}$ may have been afraid of knocking the hand when it was still tender, or having been off work for several weeks he was, perhaps, in no hurry to start again ; (3) he was advised not to start work by a lay person, as for example a compensation secretary, although his general practitioner presumably must be partly responsible if he does not sign a final certificate; (4) the hand became worse and he either returned to the clinic or attended another hospital; (5) work of the right kind was not available. The difficulty is that there is no such thing as "work" but only the work the man did before he came to the hospital, and the work he can find when he leaves it. The term "light work" can be particularly unhelpful, and some men who had been advised by the clinic to start light work said they would have liked more discussion with the clinic surgeon on the kind of work he had in mind, and whether it was likely to be available ; $(6)$ his holiday period happened to come at the time when he would normally have started work.

The Work the Men Returned to.-Table 7 shows that nearly three-quarters of the men went straight back to the jobs they were doing at the time of the injury. Sixty-five men $(21.9 \%)$ were known to have changed their jobs when they started again, but 27 of these returned to their own work later. In five instances it was not clear whether the change was temporary or permanent. Thirty-three men $(11 \cdot 1 \%)$ 
TABLE 7

RETURN TO WORK

\begin{tabular}{|c|c|c|c|c|c|c|c|c|c|c|c|c|c|c|c|c|c|c|}
\hline \multirow{3}{*}{\multicolumn{3}{|c|}{ Jobs Returned To }} & \multicolumn{16}{|c|}{ Occupation } \\
\hline & & & \multicolumn{2}{|c|}{ Mining } & \multicolumn{2}{|c|}{ Engineering } & \multicolumn{2}{|c|}{$\begin{array}{l}\text { Wood- } \\
\text { working }\end{array}$} & \multicolumn{2}{|c|}{ Unskilled } & \multicolumn{2}{|c|}{ Transport } & \multicolumn{2}{|c|}{$\begin{array}{l}\text { Building and } \\
\text { Contracting }\end{array}$} & \multicolumn{2}{|c|}{ Other } & \multicolumn{2}{|c|}{ Total } \\
\hline & & & No. & $\%$ & No. & $\%$ & No. & $\%$ & No. & $\%$ & No. & $\%$ & No. & $\%$ & No. & $\%$ & No. & $\%$ \\
\hline Same job & $\ldots$ & . & 87 & $73 \cdot 1$ & 56 & $80 \cdot 0$ & 19 & $63 \cdot 3$ & 18 & $78 \cdot 3$ & 4 & $66 \cdot 7$ & 6 & $75 \cdot 0$ & 27 & $65 \cdot 9$ & 217 & $73 \cdot 1$ \\
\hline $\begin{array}{r}\text { Different jot } \\
\text { Temporar } \\
\text { * Permanen } \\
\text { Not know }\end{array}$ & & $\begin{array}{l}\cdots \\
\cdots\end{array}$ & $\begin{array}{r}17 \\
8 \\
5\end{array}$ & $\begin{array}{r}14 \cdot 3 \\
6 \cdot 7 \\
4 \cdot 2\end{array}$ & $\begin{array}{r}3 \\
7 \\
-\end{array}$ & $\begin{array}{c}4 \cdot 3 \\
10 \cdot 0 \\
-\end{array}$ & $\begin{array}{r}3 \\
6 \\
-\end{array}$ & $\begin{array}{l}10.0 \\
20.0 \\
-\end{array}$ & $\frac{-4}{-}$ & $\overline{17 \cdot 4}$ & $\overline{2}$ & $\overline{33 \cdot 3}$ & $\frac{-}{2}$ & $\overline{25.0}$ & $\begin{array}{r}4 \\
4 \\
-\end{array}$ & $\begin{array}{l}9 \cdot 7 \\
9 \cdot 7 \\
-\end{array}$ & $\begin{array}{r}27 \\
33 \\
5\end{array}$ & $\begin{array}{r}9 \cdot 1 \\
11 \cdot 1 \\
1 \cdot 7\end{array}$ \\
\hline Not known & . & . & 2 & $1 \cdot 7$ & 4 & $5 \cdot 7$ & 2 & $6 \cdot 7$ & 1 & $4 \cdot 3$ & - & - & - & - & 4 & $9 \cdot 7$ & 13 & $4 \cdot 4$ \\
\hline Not applica & & $\cdots$ & - & 一 & - & - & 一 & - & $\div$ & - & - & - & - & - & 2 & 4.9 & 2 & 0.7 \\
\hline Total & .. & . & 119 & $100 \cdot 0$ & 70 & $100 \cdot 0$ & 30 & $100 \cdot 0$ & 23 & $100 \cdot 0$ & 6 & 100.0 & 8 & $100 \cdot 0$ & 41 & 99.9 & 297 & $100 \cdot 0$ \\
\hline
\end{tabular}

* Includes men who knew they would never return to their former employment and those who had not done so by the time of follow-up visit.

either knew that they would never return to their former employment or had not done so by the time of the follow-up visit one and a half to two and a half years after the injury. About three-quarters of those who had changed their jobs were visited in the follow-up study, and their reasons for changing will be discussed in the next section.

\section{The Follow-up}

The men who were visited in the follow-up study were selected because it seemed likely that there would be some residual disability, and they are therefore not representative of the whole group.

One hundred and fifty-seven men were selected for possible visits, but 57 of these visits were not made either because the men lived too far away (40), or they had changed their address (9), or were not in when called on (2), or because they had been called up or were ill or had died (6). The exclusion of those who lived far away from Newcastle meant that some of the morc severely injured men were not visited, since those who came from a distance often came because their injuries were too serious to be treated at a local hospital where there was no hand clinic.

Over a third of the 100 men who were visited were miners (36), and the other main occupational groups were engineers (22), woodworkers (14), and unskilled workers (10).

It was originally planned to visit men about two years after the injury, and on the whole this was done. Eighty-nine men were visited one and a half to two and a half years after the injury, and 45 of these visits were made before the two years were up and 44 after. Eleven men were visited one year to one and a half years after the injury.

Residual Disability.-The men were asked if the injury troubled them in any way and the data are set
TABLE 8

RESIDUAL DISABILITY AT TIME OF FOLLOW-UP VISIT

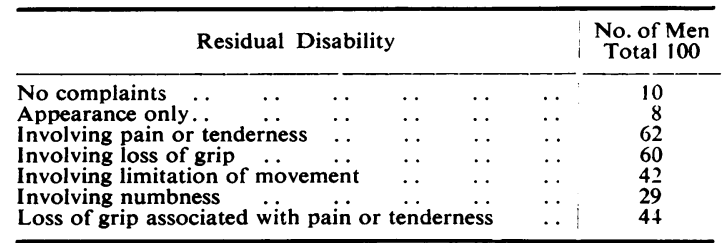

out in Table 8. No tests were made of hand and finger function, but the statements of the men were supporied by observation of the state of the hand, and, whenever possible, by noting the percentage assessment for disablement benefit made by the Ministry of Pensions and National Insurance.

The injuries were all severe, and it is therefore satisfactory that 10 men could find nothing wrong with the hand. This group is comprised of six Thiersch grafts, and four sutures of extensor tendons. Seven of these men were under 33 years and the remaining three men were between 50 and 61 . Of the 90 men who had some kind of residual disability, eight had a normally functioning hand but there was some obvious defect, for example, an amputation stump, a scar or slight discoloration, or a lumpy area of flesh where skin had been grafted. Sixty-two men complained of pain or tenderness, and 60 suffered some impairment of grip, and 44 of these men complained of loss of grip as well as pain or tenderness. Tenderness always referred to some sensitivity to touch especially at the finger tip or amputation stump, and those who complained of pain usually meant that the hand was painful in cold weather only. A few men complained of occasional attacks of cramp or aches in the hand, and one man said that his hand ached all the time and his doctor gave him sleeping pills because of this. Forty-two 
men complained of limitation of movement caused by stiffness in the hand or fingers.

An attempt was made to relate disability to specific injuries or surgical treatments, but sometimes where the hand had received more than one kind of injury it was not possible to establish any direct relationship between these injuries and the resulting disabilities.

Out of a total of 51 men who had received skin grafts, 23 complained of soreness of the graft area and 12 men said there was no feeling in the graft. There were 31 Thiersch and 13 post-auricular grafts, and of these, 10 men (eight Thiersch and two post-auricular) had no complaints to make about the graft and nine others (seven Thiersch and two post-auricular grafts) had a perfect functional result but the graft area was clearly visible. Five men said that in the early stages the graft cracked easily or came up in pimples, and three men were troubled with the graft bleeding heavily when it was knocked. Seven men found the nail was a nuisance, either because there was not enough flesh underneath it or because it was not growing normally.

Twenty men had had amputations (15 surgical and five traumatic) not treated by grafting, and six of these were perfectly satisfied with the result. The remaining 14 men usually complained of numbness or stiffness, and one man was not at all pleased with the amputation stump which was red and bulbous, and he said he kept knocking it with painful results. Those who were left with stiff finger remnants said they would have preferred an amputation at the base of the finger, since the stump tended to get in the way.

Tendon injuries were responsible for several crippling disabilities. Of 24 men with tendon injuries (14 extensor, 10 flexor) five were left with normal function. In all these five cases the injuries had been to the extensor tendon and in each case the injury had been treated by primary repair. The usual disability was stiffness of the finger and in some cases there was no movement at all. Three men had the finger amputated later and one of these men went to another hospital for the amputation. The usual treatment of tendon injuries was primary repair, but no attempt was made to repair five of these injuries, and there was one graft. Four of the extensor tendon and two of the flexor tendon injuries were associated with bone injuries in the same finger, and this obscured the relationship between the disability and its cause.

There were four bone or joint injuries uncomplicated by any other kind of injury, and of these, one man had no complaint to make about the bone injury. The other three men complained of stiffness or pain, or a weakness of the hand causing some loss of grip.

Loss of grip was a characteristic of nearly all these disabilities.

\section{Disablement Benefit}

It is obvious that many of the men suffered very severe disabilities, and this is confirmed by Table 9

TABLE 9

DISABLEMENT BENEFIT AWARDED AT TIME OF FOLLOW-UP VISIT

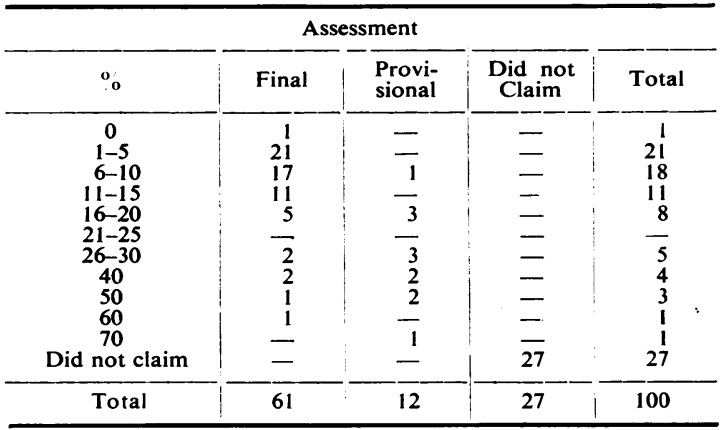

which gives the disablement expressed as a percentage by the medical boards of the Ministry of Pensions and National Insurance. Twelve men were considered to have hand conditions which were liable to change appreciably with the passage of time, and they were therefore given provisional assessments to cover the period between one examination and the next. About two-thirds of those who claimed were assessed at between $1 \%$ and $15 \%$, and the highest permanent assessment was $60 \%$ for a man who had lost all the fingers of his right hand. Twenty-seven men did not claim benefit, and this includes the 10 men who had nothing wrong with the hand, and two of these were not eligible for benefit since the injury had not occurred at work. This leaves 17 men who had some residual disability and who could have applied for benefit but did not do so. None of these men had gross hand disabilities, but had they applied they would probably have been assessed somewhere between $1 \%$ and $10 \%$. A few of these men said they would apply for benefit after the follow-up visit, and two of them wrote later to say that they had been assessed at $5 \%$. Usually when the men did not apply for benefit it was because they did not know about it, or because they thought they were not eligible. Some of the men considered their disability was too trifling to bother with. At the other extreme were those who were not satisfied with the assessment awarded to them. Five men had appealed against the medical board's decision, and three 
others were considering an appeal. The five appeals were all successful.

\section{The Psychological Effects of the Injury}

The psychological effects of injury are important but they are hard to assess.

At the start of their incapacity some of the men were afraid of losing their jobs because of a crippling hand disability, but by the time of the follow-up visit most of them knew the extent of their disability and had accommodated themselves to it. Fear of injuring the hand again was mentioned by some men, and those who had sustained severe injuries as a result of a machinery accident were sometimes sickened by the accident so that they could not bring themselves to work the same machine again, even if they were physically capable of doing so.

There was no evidence to support the idea that a manual worker does not mind about the cosmetic result of treatment for a hand injury. Men of all ages and occupations were remarkably self-conscious about the appearance of their hands, and a man with an obviously crippled hand often did his best to hide the disability. One or two men elected to have a stiff finger amputated, but several men preferred to keep stiff, straight fingers even if they were useless to them, partly because they did not want to lose more time from work through another operation, but also because they did not like the idea of having an obviously defective hand. Two men felt there was a prejudice against disabled men where they worked, and consequently they did not want to have any obvious disability. The men disliked ugly amputation stumps or rough graft areas. Some were sickened by the feel of the graft, and one man was troubled because his wife was upset by the sight of his thumb nail growing like a piece of thin wire through a hole the size of a pin head at the edge of the graft area.

One man reacted in a neurotic manner to his injury, but he was the only man in the series whose residual disability was out of all proportion to the injury.

Case 7.- This man, a miner, lacerated the left index finger and three months later he returned to the clinic with a painful scar, and he appeared to be suffering from causalgia. By the end of two years he had had all the recognized methods of treatment except amputation, and this was considered inadvisable. When he was visited two and a half years after the accident there appeared to be nothing wrong with the finger, but he complained that whenever he bent it he felt a pain shooting up the arm, down the spine, at the back of the head and in the stomach, and sometimes the pain was so severe that he was "paralysed ". At one time he thought the pain was giving him chest trouble, and he persuaded his doctor to let him have a chest radiograph. The pain was very real to this man, and, in its own way, his condition was a genuine one. He had changed his job from work on the rolley way to datal work on the conveyor belt at a weekly loss of $£ 2$ or $£ 3$, and he was not therefore likely to gain anything financially by prolonging his illness. According to the manager at his pit, in the past he had been a good workman, but after his injury the man said that even light work was almost too much for him as he was often " in agony " and, had to let his mates take over for him. Altogether he was off work for one year and ten months because of his injured. finger. He was constantly appealing for an increase to his disability assessment, and when he was last heard of three years after the accident he was still battling with the Ministry of Pensions and National Insurance.

The Occupational and Social Effects of the Injury

Forty-seven of the 65 men who had changed their jobs were visited. Twenty-eight were still not back at their former employment, and of these five men had changed their work for reasons which were not connected with the injury, and one man was fit enough to do his old job but his firm was not willing to give him his old job back as he was not a good worker. Twenty-two men $(7 \%)$ were unable to do their pre-injury job because of hand disabilities. Eight of these men had gross disabilities affecting the whole hand, and these men all changed to jobs which were virtually one handed, e.g., operating the conveyor belt buttons down a pit, supervising others, or doing storekeeping work. One man found he could lay linoleum using his crippled hand as a clamp and getting a work mate to help him with anything he could not manage himself. Others found that stiff or painful fingers, especially thumbs and index fingers, were a great handicap since the hand grip was impaired, and they were often unable to pick up small objects or to use hand tools because of these disabilities. Some men were too slow to stand the pace of a machine or to keep up with a team, and others said they were nervous of machines since their accident. Three men had changed their jobs because they used to do outside work, and cold weather made their hands unbearably painful. Six men left the firms they used to work for, and with one exception they all found new work on their own initiative. The exception was a bakery worker who became unemployed because his firm could not give him suitable work, and he was referred to the Disablement Resettlement Officer of the Ministry of Labour. On the whole, employers were good at finding suitable jobs for their disabled workers. One man was told that he must register as disabled before he could be given a light job, but once he had done this there was no difficulty in finding him work he could do. 
A severely disabled hand may affect a man's life in many ways, and several men were handicapped in their hobbies although they could manage their jobs all right. Some had had to cut down on their gardening activities, either because they were no longer able to feel or pick up small objects or they had not the grip to use garden implements. Several men were no longer able to play musical instruments. Basket making, embroidery, upholstery work, motor cycling, table tennis, and body building exercises, were all activities which the men found they could no longer do. Barclay (1955a) found that patients with finger tip injuries were often unable to do up their studs and buttons, and a few of the men in the present series complained of the same difficulty, usually because of stiffness or soreness of the index or middle fingers.

In general the men adjusted themselves to their disabilities remarkably well. It is seldom necessary to use any particular finger or part of the hand, and several of the men adapted the function of the injured hand so that the injured part was not used.

\section{Discussion}

The evidence of the present study indicates that although injuries to the hand often cause severe permanent physical disabilities, there is not often any occupational handicap. All but 10 of the 100 men who were visited had some kind of disability, and it is reasonable to suppose that there was a similar proportion of disabilities among the severely injured men who were not visited. But in the series as a whole only 33 men made a permanent change of work and at least five of these changed their jobs for reasons which were not connected with the injury. All the men were able to find work of some sort and only one man experienced any kind of difficulty in finding a job.

Hand injuries are important chiefly because of their frequency and of their cost. It is not possible to say how many industrial accidents involve injuries to the hand but estimates indicate that the figure must be a high one. Rank and Wakefield (1953) quote figures showing that approximately one in every three persons drawing industrial injury benefit in this country in 1949 did so for a hand injury. A more recent estimate from the Ministry of Pensions and National Insurance states that out of a total of 741,000 spells of injury benefit in 1951 there were 154,000 spells $(21 \%)$, caused by hand injuries i.e., approximately one in five. The incidence of hand accidents varies from industry to industry and the present study suggests that liability to serious hand accidents is particularly great in the pits and in industries using machinery, especially wood- working machinery. It is clear that the cost of these injuries is considerable, both to the community and to the individual. People with injured hands pay a high cost in terms of pain and disability. Heavy damages are often paid to men involved in hand accidents, and in 1951 the annual cost to the country in injury benefit paid for hand injuries was approximately $£ 2 \cdot 2$ million. Work is held up and disorganized when accidents happen, and production is lost when a man has to be off work. Many hand accidents are avoidable, and industry would profit if more attention were paid to the causes and prevention of injuries to the hand.

\section{Summary}

The aims of the research were first, to find out the causes of hand injuries and to discuss ways of preventing them; secondly, to find out how much time and money were lost through hand injuries ; and thirdly, to assess the long-term effects of the injuries.

The men interviewed were attending the Hand Clinic of the Department of Surgery in the Royal Victoria Infirmary, Newcastle upon Tyne. Two hundred and ninety-seven men were interviewed during the period from March, 1952, until December, 1952.

Three-quarters of the injuries were to the fingers only. The injuries were all severe enough to keep the men off work.

About a third of the injuries were caused by machinery, and most of these accidents happened to workers in the engineering and woodworking trades. Handling goods ranked next in importance as a cause of injury, and in the pits the main causes of injury were falls of stone, and moving tubs or trams.

Speed of working, inadequately guarded or badly maintained machines, faulty material, inexperience, and misunderstanding were given as reasons for accidents happening. Miners suggested that haulage accidents would be prevented if tub buffers were lengthened.

Weekly income loss while the injured man was off work varied around a mid-point of $£ 310$ s., but this loss was often made up later if the man received disablement benefit, tax relief, or damages.

Over three-fifths of the men were off work for less than eight weeks and the median duration for all the men was seven weeks. Over half the men who had been advised to start work by the clinic surgeon delayed doing so for two weeks or more. Sixty-five men went back to different jobs, but 27 of these later returned to their own work. Thirtythree men were known to have made a permanent change of employment. 
One hundred of the more severely injured men were visited at home about two years after the injury. All but 10 of these men had some degree of residual disability. An attempt was made to assess the occupational, social, and psychological effects of the injuries. Physical disabilities were often severe but there was rarely any occupational handicap.

I wish to thank Professor R. C. Browne for his advice and general help throughout the work, and also to acknowledge the statistical assistance given by Mr. D. Newell and Mr. H. Campbell. I am very grateful to Mr. Dennis Newman, statistician to the Ministry of Pensions and National Insurance, and his staff for producing the official figures for the incidence of hand injuries. The work was made possible by the help and interest received from the staff and patients of the Hand Clinic of the Department of Surgery in the Royal Victoria Infirmary, Newcastle upon Tyne. I am also greatly indebted to Mrs. M. Berry for secretarial assistance, and to Mrs. D. Weightman for her help with the calculations.

\section{REFERENCES}

Barclay, T. L. (1955a). Brit. J. Plast. Surg., VIII, 38

- (1955b). Personal communication.

Rank, B. K., and Wakefield, A. R. (1953). Surgery of Repair as Applied to Hand Injuries. Livingstone, London and Edinburgh. Whitfield, J. W. (1946). "Accidents to Coal Miners-Haulage and Pit Bottom Accidents." M.R.C. Applied Psychology Research Unit, Report No. 36.

Wilkes, Ruth (1954). British Journal of Industrial Medicine, $11,269$.

\section{THE JANUARY (1956) ISSUE}

The January (1956) issue contains the following papers :-

The Prevalence of Pneumoconiosis and Tuberculosis among Earthenware Towers. By E. Posner.

A Report on the Absence of Pneumoconiosis among Workers in Pure Limestone. By S. Bridge Davis and G. Nagelschmidt. Further Studies of the Dust in Lungs of Coal-miners. By E. J. King, B. A. Maguire, and G. Nagelschmidt.

Cardiac Hypertrophy in Coalworkers' Pneumoconiosis. By W. R. L. James and Arthur J. Thomas.

Respiratory Function in Men Casting Cadmium Alloys.

Part I : Assessment of Ventilatory Function. By G. Kazantzis.

Part II : The Estimation of the Total Lung Volume, its Subdivisions, and the Mixing Coefficient. By R. St. J. Buxton.

The Action of Variable Amounts of Tridymite, and of Tridymite Combined with Coal, on the Lungs of Rats. By Daphne Attygalle, E. J. King, C. V. Harrison, and G. Nagelschmidt.

Toxicological Investigations on Dimethylformamide. By W. Massmann.

Dermatitis from Mansonia Wood. By L. B. Bourne.

A Survey of Dock Labour Accidents in the Port of London. By W. J. Shaw.

Miscellanea :

A Study of Variations in Output. By I. M. Richardson and W. Z. Billewicz.

Shell Haven Medical Centre. By Gunilla Liddle.

British Occupational Hygiene Society :

The Use and Abuse of Protective Equipment. By C. N. Davies

Report of Ordinary Scientific Meeting

Obituary : Carl M. Peterson, M.D.

Book Reviews

A number of copies are still available and may be obtained from the Publishing Manager, British Medical Association, Tavistock Square, W.C.1, price 12s. 6d. 